内在性ドパミンとプロテアソーム活性によるドパミンニューロン死の制御機構

泉 安彦, ${ }^{*}$ 久米利明, 赤池昭紀

\title{
Regulation of Dopaminergic Neuronal Death by Endogenous Dopamine and Proteasome Activity
}

\author{
Yasuhiko IzUmI, ${ }^{*}$ Toshiaki Kume, and Akinori AKAIKE \\ Department of Pharmacology, Graduate School of Pharmaceutical Sciences, Kyoto University, \\ 46-29 Yoshida-Shimoadachi-cho, Sakyo-ku, Kyoto 606-8501, Japan
}

(Received August 28, 2010)

\begin{abstract}
Parkinson disease is one of the most common neurodegenerative disorders and is characterized by the selective loss of dopaminergic neurons in the substantia nigra. Although endogenous dopamine itself could serve as a vulnerability factor for dopaminergic neurons, the mechanism by which dopamine contributes to dopaminergic neuronal death remains unknown. In addition, although a decrease in proteasome activity was found in patients with sporadic Parkinson disease, the relationship between the ubiquitin-proteasome system and dopaminergic neuronal death remains to be elucidated. Here we provide an overview of the roles of endogenous dopamine and proteasome activity in dopaminergic cell death. Treatment of catecholaminergic PC12 cells with the herbicide paraquat, a potential risk factor for the development of Parkinson disease, induced an increase in dopamine content, and depletion of intracellular dopamine suppressed paraquat-induced cytotoxicity. Although glutathione, which scavenged dopamine oxidation intermediate, provided almost complete protection against dopamine-mediated toxicity, catalase provided only partial protection against cell death caused by dopamine. These data suggest that the generation of dopamine oxidation intermediate, rather than that of reactive oxygen species, plays a pivotal role in dopamine-induced toxicity. Moreover, treatment with paraquat induced a decrease in proteasome activity, and proteasome inhibition suppressed dopamine-mediated cytotoxicity. Suppression of proteasome activity stimulated the NF-E2-related factor 2 (Nrf2) -antioxidant response element (ARE) pathway, and elevated $\gamma$-glutamylcysteine synthetase mRNA and glutathione content. Furthermore, suppression of the paraquat-induced increase in gluthathione content exacerbated paraquat toxicity. These results suggest that the reduction of proteasome activity may be involved in cellular defense mechanisms against dopamine-mediated paraquat toxicity.
\end{abstract}

Key words - endogenous dopamine; Parkinson disease; proteasome activity; NF-E2-related factor 2 (Nrf2) -antioxidant response element (ARE) pathway

\section{1. はじめに}

パーキンソン病は中脳黒質一線条体ドパミンニ ユーロンの変性・脱落を特徵とし, 線条体ドパミン 量の低下に起因する錐体外路症状を示す神経変性疾 患である。棟における有病率は人口 10 万人に対 して 100-150 人で, アルツハイマー病についで 2 番 目に多い神経変性疾患である。現在のところ，パー キンソン病に対する治療はドパミン補充療法など対

京都大学大学院薬学研究科薬品作用解析学分野 ( T606 -8501 京都市左京区吉田下阿達町 46-29)

*e-mail: yizumi@pharm.kyoto-u.ac.jp

本総説は, 日本薬学会第 130 年会シンポジウムS61 で 発表したものを中心に記述したものである.
症療法がほとんどであり，神経変性を抑制する根治 療法は確立していない。パーキンソン病は進行する と黒質ドパミンニューロン以外に青斑核ノルアドレ ナリンニューロンなども脱落することが知られてい たが, 最近, パーキンソン病発症早期において，心 臓交感神経終末が減少していること, 1,2) また, 瞳孔 交感神経終末も脱落している可能性があることが報 告され, ${ }^{3)}$ 早期診断への応用に期待が高まってい る.これらの臨床知見から，パーキンソン病は全身 のカテコラミン作動性神経が障害を受けていると捉 えることができる。パーキンソン病の発症には環境 因子, 遺伝的素因, 内在性神経毒などの複数の病因 が複雑に絡み合っていると考えられているが，カテ 
コラミン神経が特に脆弱であることからカテコラミ ン神経固有の脆弱性因子の存在が想定される。その 有力な候補がカテコラミン自身である。本稿では, カテコラミンの 1 つである内在性ドパミンがどのよ うにドパミンニューロン死に関与しているか，及 び，それを制御する機構について紹介する。

2. 内在性ドパミンによるドパミンニューロン死 の制御

ドパミンを含むカテコラミンはシナプス小胞内で は安定ではあるが，小胞外のカテコラミンは容易に 自動酸化を起こし活性酸素種を生成するため，カテ コラミン神経の危険因子として考えられている，実 際，内在性ドパミンを減少させると，パーキンソン 病発症との関連が疑われる遺伝子産物である $\alpha$ ヌクレインやパイエル受容体過剩発現によるドパミ ンニューロン死が抑制されることが報告されてお り, ${ }^{4,5)}$ 筆者らも農薬のロテノン及び興奮性アミノ酸 であるグルタミン酸によって引き起こされるドパミ ンニューロン死に内在性ドパミンが関与しているこ

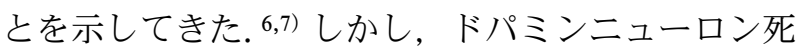
における内在性ドパミンの役割はいまだ不明な点が 多い.

2-1. パラコート誘発ドパミンニューロン死にお ける内在性ドパミンの関与＼cjkstart疫学調査により, 種 々の農薬の曝露がパーキンソン病の危険因子として 注目されており, ${ }^{8}$ 除草剤であるパラコートはその 候補物質の 1 つである. ${ }^{9)}$ パラコートは，in vivoに おける腹腔内投与により黒質ドパミンニューロンを 選択的に変性させる10)ことが知られているが，その ドパミンニューロン選択的な毒性発現機序の詳細に ついては明らかにされていない。そこで，パラコー 卜誘発細胞死への内在性ドパミンの関与について, ドパミンを産生・貯蔵・遊離するラット副腎髄質褐 色細胞腫 PC12 細胞をドパミンニューロンのモデル として用いて検討を行った. ドパミン生合成の律速 酵素であるチロシンヒドロキシラーゼの阻害薬 $\alpha$ methyl-p-tyrosine によって細胞内ドパミン量を減少 させたところ，PC12 細胞はパラコート毒性に対し て抵抗性を示した。また，細胞内ドパミン量につい て検討したところ，パラコート処置により 9-12 時 間をピークに一過性の上昇が観察された（未発表 データ)。これらの結果から，パラコート処置によ り上昇した細胞内ドパミンが毒性発現に重要な役割
を果たしていることが示唆された。

2-2. ドパミンによる毒性発現におけるドパミン 酸化中間体の役割 ドパミンの自己酸化過程で は，スーパーオキシドや過酸化水素などの活性酸素 種（reactive oxygen species; ROS）を発生させなが ら，自身は o-quinone や aminochrome といつた酸 化中間体を経てメラニンに変換する（Fig. 1)。次 に，ドパミンが毒性を発現する機序を明らかにする ために各種抗酸化薬の作用について，ドパミンニ ユーロンの株化細胞であるがドパミンを産生しない ヒト神経芽細胞腫 SH-SY5Y 細胞を用いて検討し た。チオール抗酸化物質である還元型グルタチオ ン $(\mathrm{GSH}), N$-acetyl-L-cysteine (NAC), L-cysteine (Cys) はドパミン毒性を濃度依存的に抑制したが [Fig. 2(A)]，スーパーオキシドドナーである xanthine/xanthine oxidase 毒性及び過酸化水素毒性を ほぼ完全に抑制する過酸化水素除去酵素カタラーゼ

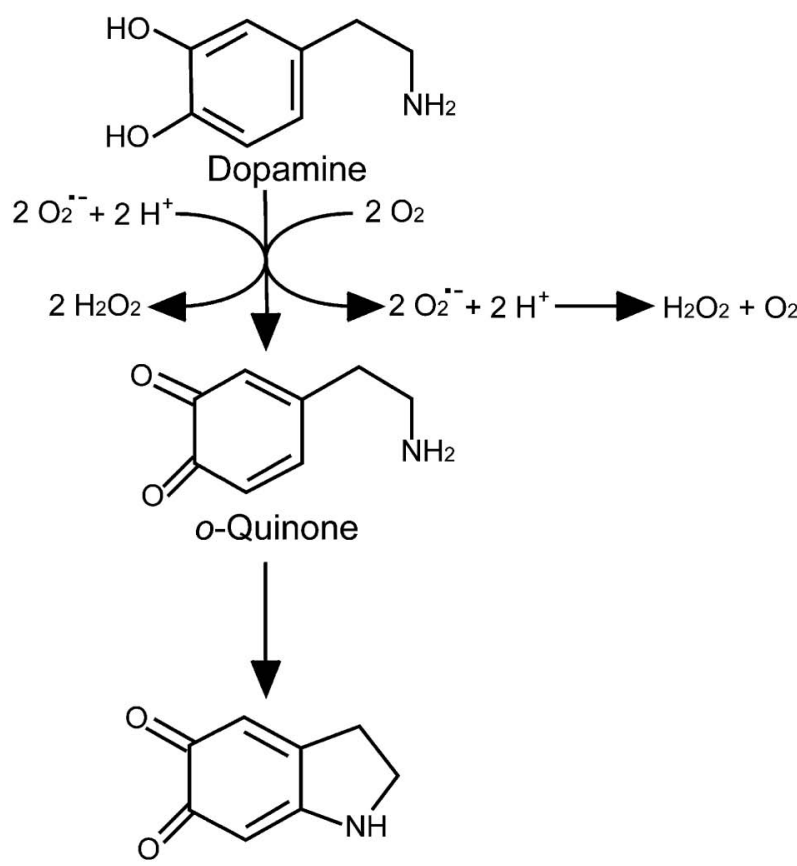

Aminochrome

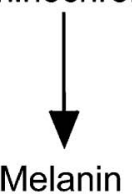

Fig. 1. Auto-oxidation Reaction of Dopamine

Dopamine is easily oxidized by molecular oxygen and superoxide anion at physiological $\mathrm{pH}$. During auto-oxidation, superoxide anion and hydrogen peroxide are produced and the corresponding oxidation intermediates, $o$-quinone and aminochrome, are formed. Finally, dopamine oxidation intermediates are polymerized into melanin. 

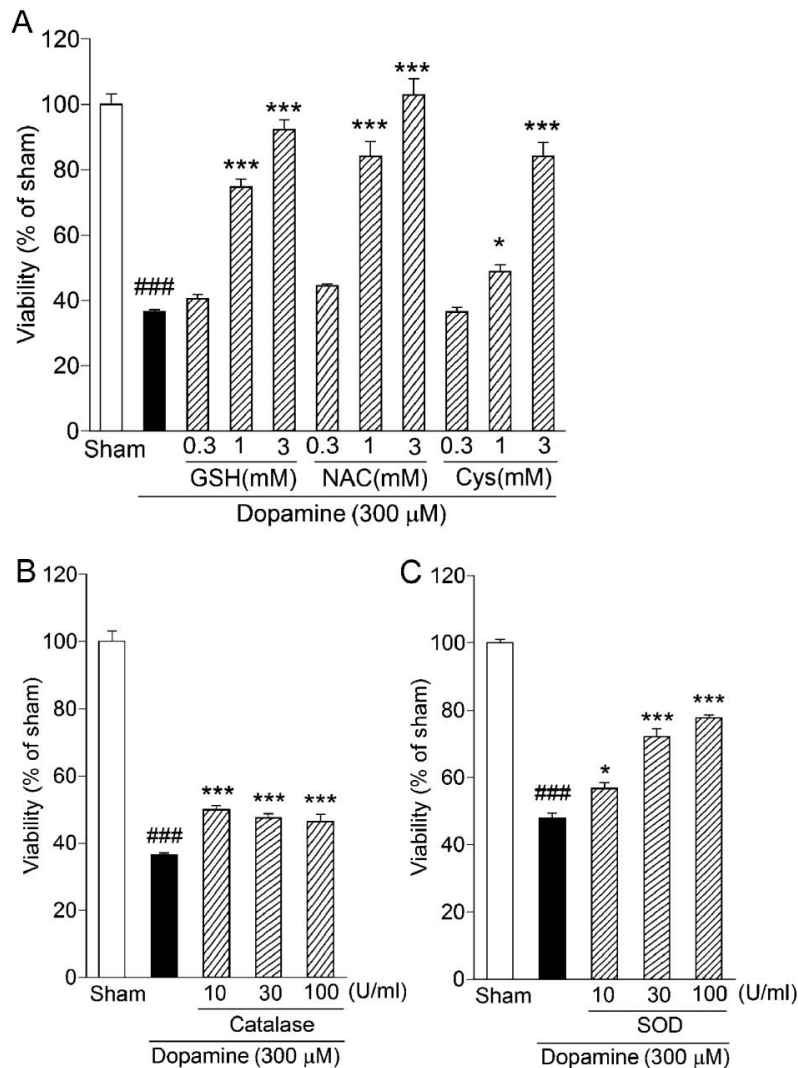

Fig. 2. Effects of Antioxidants on Dopamine-induced Cell Death in SH-SY5Y Cells

A: Effects of thiol antioxidants on dopamine-induced toxicity. B: Effect of catalase on dopamine-induced toxicity. C: Effect of SOD on dopamine-induced toxicity. SH-SY5Y cells were exposed to dopamine for $24 \mathrm{~h}$ in the presence or absence of various concentrations of GSH, NAC, Cys, catalase and SOD. Cell viability was determined by 3- (4,5-dimethylthiazol-2-yl) -2,5diphenyltetrazolium bromide (MTT) assay. The viability of SH-SY5Y cells is presented as a percentage relative to sham treatment $(100 \%)$. \#\#\# $p<0.001$ vs. sham treatment. ${ }^{*} p<0.05,{ }^{* * *} p<0.001$ vs. dopamine alone.

のドパミン毒性に対する保護作用は限定的なものあ った [Fig. 2(B)]。一方，ドパミン毒性に対し superoxide dismutase（SOD）は濃度依存的に保護作 用を示した [Fig. 2(C)]。これらの結果から，ドパ ミン毒性は単純な酸化ストレスではなく，チオール 抗酸化物質及びスーパーオキシドの除去により特異 的に抑制されることが明らかとなった。

そこで，ドパミン酸化中間体を HPLCにより分 離し電気化学検出器を用いて検出した. ドパミン酸 化中間体である o-quinone と aminochrome は，い ずれもドパミン酸化 1 時間後をピークとして一過性 に生成した。ドパミン酸化中間体に対する抗酸化薬 の作用について検討するために，まず，抗酸化薬の 存在下ドパミンを 1 時間酸化させた。チオール抗酸 化物質の存在下ではドパミン酸化中間体量は検出限

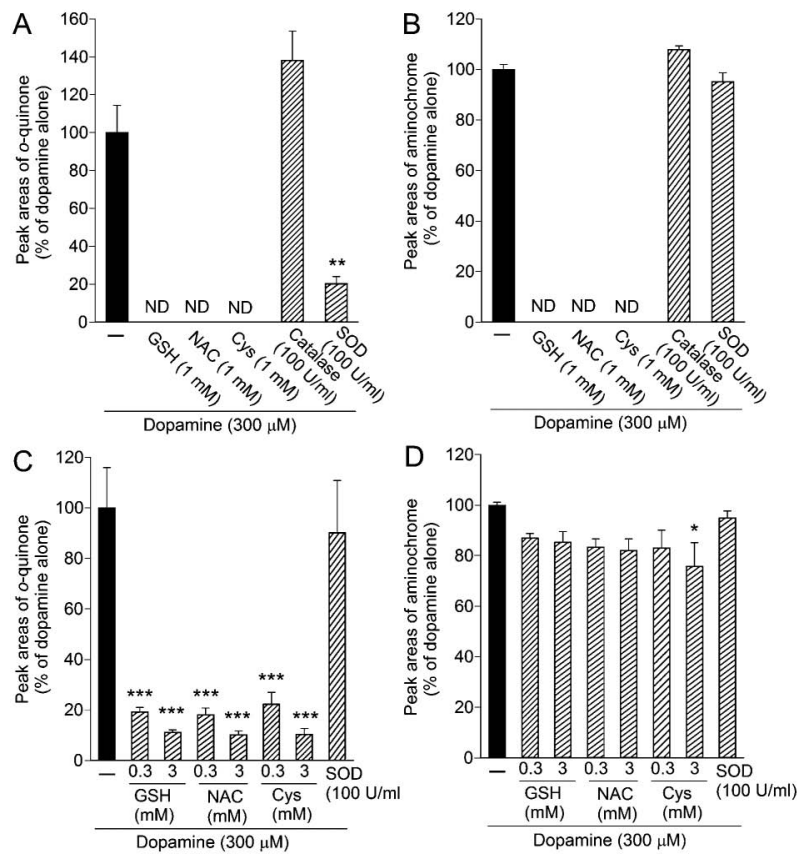

Fig. 3. Effects of Antioxidants on Dopamine Oxidation Intermediates

(A, B) Generation of dopamine oxidation intermediates in the presence of antioxidants. Dopamine $(300 \mu \mathrm{M})$ was oxidized for $1 \mathrm{~h}$ in the presence or absence of antioxidants. (C, D) Interaction of antioxidants on dopamine oxidation intermediates. Antioxidants were incorporated into reaction solution after dopamine $(300 \mu \mathrm{M})$ was oxidized for $1 \mathrm{~h} .{ }^{*} p<0.05,{ }^{* *} p<0.01,{ }^{* * *} p<$ $0.001 \mathrm{vs}$. dopamine alone. ND, not detected.

界以下で，カタラーゼの存在下では影響はなく， SOD の存在下では $o$-quinone 量のみ減少した [Figs. 3(A) and (B)]。次にドパミン酸化中間体に 対してチオール抗酸化物質とSOD が直接作用する か検討するために，ドパミンを 1 時間自動酸化させ 生成したドパミン酸化中間体に抗酸化薬を加えたと ころ, チオール抗酸化物質の場合 $o$-quinone 量は減 少したが, aminochrome 量に大きな変化はなかつ た．SODの場合いずれにも影響がなかった［Figs. 3(C) and (D)]。これらの結果より，チオール抗酸 化物質は $o$-quinone を直接除去すること及びスー パーオキシドは $o$-quinone の生成過程を促進するこ とが示唆された，以上をまとめると，パラコートを 処置すると細胞内ドパミン量が増え，ドパミン酸化 により生成した o-quinone 又は aminochrome が毒 性発現に寄与していることが考えられる. ${ }^{11)}$

これまでの研究で，選択的ドパミンニューロン死 に内在性ドパミンが重要な役割を果たすことが明ら かにされてきた，そのドパミン毒性の主要なメディ エーターであるドパミン酸化中間体を解毒する抗酸 
化物質, 特にグルタチオンを細胞内で増加させるこ とがパーキンソン病における神経保護療法に有効で あると考えられる.

\section{3. プロテアソーム活性によるドパミンニューロ ン死の制御}

パーキンソン病において残存するドパミンニュー ロン内に Lewy 小体と呼ばれる細胞質封入体が観察 されており，その病態形成にタンパク品質管理障害 の関与が推定されている。ユビキチンープロテア ソームシステム（UPS）はターゲット特異的な細 胞内タンパク分解機構であり，転写因子やシグナル 伝達タンパク及びミスフォールドしたタンパクの分 解に重要な役割を担っている。遺伝性パーキンソン 病の原因遺伝子である $P A R K 2$ がユビキチンリガー ゼ E3 である parkin, PARK5 は脱ユビキチン化酵 素である UCH-L1 であることに加えて，孤発性 パーキンソン病患者の剖検脳においてもプロテア ソーム活性が低下していることやプロテアソームの サブユニットが減少していること ${ }^{12)}$ が報告され，近 年，パーキンソン病におけるUPS の役割は国内外 で大きな関心を集めてきた。UPS の機能不全は異 常タンパクの蓄積や小胞体ストレスを誘発すること が知られており，重度のプロテアソーム活性の低下 は細胞死を惹起する。一方，筆者らのグループは， 軽度にプロテアソーム活性を阻害するとタンパクの 凝集体は形成するが，ドパミンニューロン死はむし

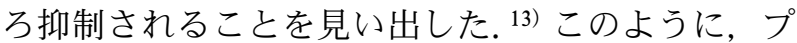
ロテアソーム活性の低下の意義，すなわち，プロテ アソーム活性の低下がドパミンニューロン死に与え る影響についてはまだ議論の余地があるところだと 考えられる。

3-1. パラコート誘発プロテアソーム活性低下の 意義パラコート処置によるプロテアソーム活性 の影響を検討するために，プロテアソーム感受性蛍 光タンパク ZsProSensor-1 を PC12 細胞に強制発現 させた．ZsProSensor-1 は通常条件ではプロテア ソームにより速やかに分解されているため蛍光を発 しないが，プロテアソーム活性が低下すると分解が 抑制されることで, 細胞内に蓄積し緑色蛍光強度が 増大する。 フローサイトメトリを用いて ZsProSensor-1 の蛍光強度を測定したところ，パラコート処 置により時間依存的なプロテアソーム活性の低下が 観察された。このパラコートによるプロテアソーム
活性低下の意義を探るため, パラコートと同時にプ ロテアソーム阻害薬 MG-132 を処置したところ, パラコート毒性を有意に抑制した。さらに，ドパミ ン誘導体でドパミン神経毒である 6-hydroxydopamine（6-OHDA）による細胞死に対して，プロテ アソーム阻害薬である lactacystin 24 時間前処置 することで濃度依存的に保護作用を示した [Fig. 4 (A) ].したがって，パラコートにより低下したプ ロテアソーム活性は，ドパミンを介する細胞死を抑 制する方向に作用することが示唆された。

\section{3-2. プロテアソーム活性低下による細胞保護作} 用機序 ドパミンと同様に 6-OHDA は容易に自 動酸化し ROS を産生することが知られている. プ ロテアソーム活性低下による細胞保護作用機序を解 明するために, 細胞内 ROS 産生を蛍光指示薬 $2^{\prime}, 7^{\prime}$ dichlorofluorescin diacetate, acetyl ester (DCF-DA) を用いて検討したところ，プロテアソーム阻害薬を 前処置した PC12 細胞では 6-OHDA による ROS 産 生が低下していた [Fig. 4(B)]。細胞内の主要な抗 酸化因子であるグルタチオンを定量したところ，プ ロテアソーム阻害薬により濃度依存的な細胞内グル タチオン量の増大が観察された $[$ Fig. 4(C)]。さら に, グルタチオン合成の律速酵素である $\gamma$-glutamylcysteine synthetase $(\gamma$-GCS) の mRNA 量もまたプ ロテアソーム阻害薬により上昇していたことから, $\gamma$-GCS 遺伝子の転写誘導が示唆された。 $\gamma$-GCS 遺 伝子のプロモーター領域にある antioxidant response element（ARE）に転写因子 NF-E2-related factor 2（Nrf2）が結合することで転写が開始され る. Nrf2 はプロテアソームにより分解されること から, ${ }^{14)}$ プロテアソーム活性の低下と Nrf2-ARE 経 路の関与について検討を行ったところ，プロテア ソーム阻害薬により Nrf2 の蓄積及び核内移行，さ らには ARE 依存性的な転写活性の上昇 [Fig. 4 (D) ] が確認された。各種キナーゼ阻害薬を用いた 薬理学的検討より, p38 mitogen-activated protein kinase (MAPK) の阻害薬 SB203580 がプロテアソー 厶阻害薬による Nrf2 の核内移行, $\gamma$-GCS mRNA 量の増加及び細胞グルタチオン量の上昇を抑制した [Figs. 5(A) and (B)]. また, プロテアソーム阻害 薬の処置によって p38 MAPK の一過性のリン酸化 が観察されたことから，プロテアソーム活性の低下 は Nrf2 の蓄積を惹起し，p38 MAPK のリン酸化を 
A

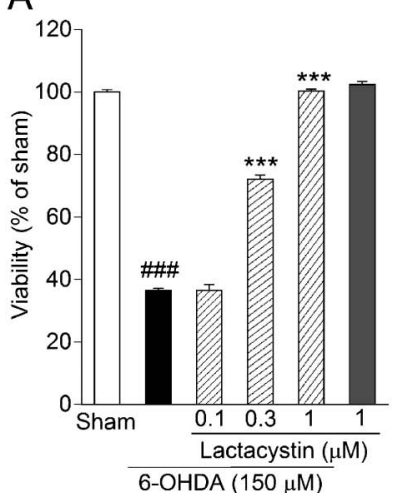

C

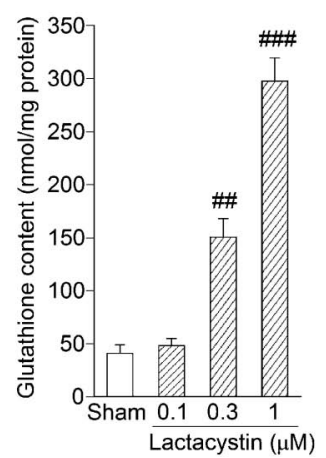

B
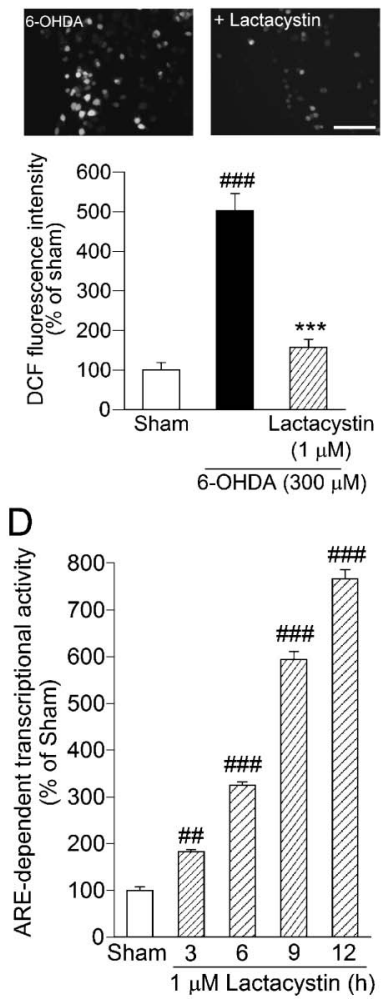

Fig. 4. Protective Effect on 6-OHDA Toxicity by Proteasome Inhibition in PC12 Cells

A: Effect of lactacystin on 6-OHDA-induced cytotoxicity in PC12 cells. $\mathrm{PC} 12$ cells were pre-treated with lactacystin for $24 \mathrm{~h}$ and exposed to 6-OHDA for $24 \mathrm{~h}$. B: Effect of lactacystin on 6-OHDA-induced ROS production. The level of intracellular ROS was measured with DCF-DA. PC12 cells were pre-treated with lactacystin for $24 \mathrm{~h}$, incubated with phosphate-buffered saline containing DCF-DA for $20 \mathrm{~min}$, and exposed to 6-OHDA for $30 \mathrm{~min}$. Formation of ROS in the cells was evaluated by the fluorescence intensity of 80-120 randomly selected cells. C: Effect of lactacystin on glutathione content. Glutathione concentrations were determined by 5,5'-dithiobis- (2nitrobenzoic acid) (DTNB) method. PC12 cells were treated with lactacystin for $24 \mathrm{~h}$. D: Effect of lactacystin on ARE-dependent transcriptional activity. ARE-dependent transcriptional activity was determined by luciferase reporter assay. PC12 cells were treated with lactacystin for indicated periods. Scale bar $=100 \mu$ m. ${ }^{\# \#} p<0.01, \# \# p<0.001 v s$. sham treatment. ${ }^{* * *} p<0.001 v s$. 6-OHDA alone.

介して Nrf2-ARE 経路を活性化することで細胞内 グルタチオン量を上昇させることが明らかとなつ た。さらに，プロテアソーム阻害薬による細胞保護 作用は，p38 MAPK 阻害薬の同時適用により抑制 されたことより [Fig. 5(C)]，プロテアソーム活性 の低下は p38 MAPK 活性化を介してグルタチオン 量を増大させることで細胞保護作用を示すことが示 された. ${ }^{15)}$

最後に，パラコート処置により低下したプロテア ソーム活性に視点を戻すとする。 パラコート処置に よってもまた, ARE 依存的な転写活性の上昇, そ れに引き続く $\gamma$-GCS mRNA 量の増加及び細胞内グ

A
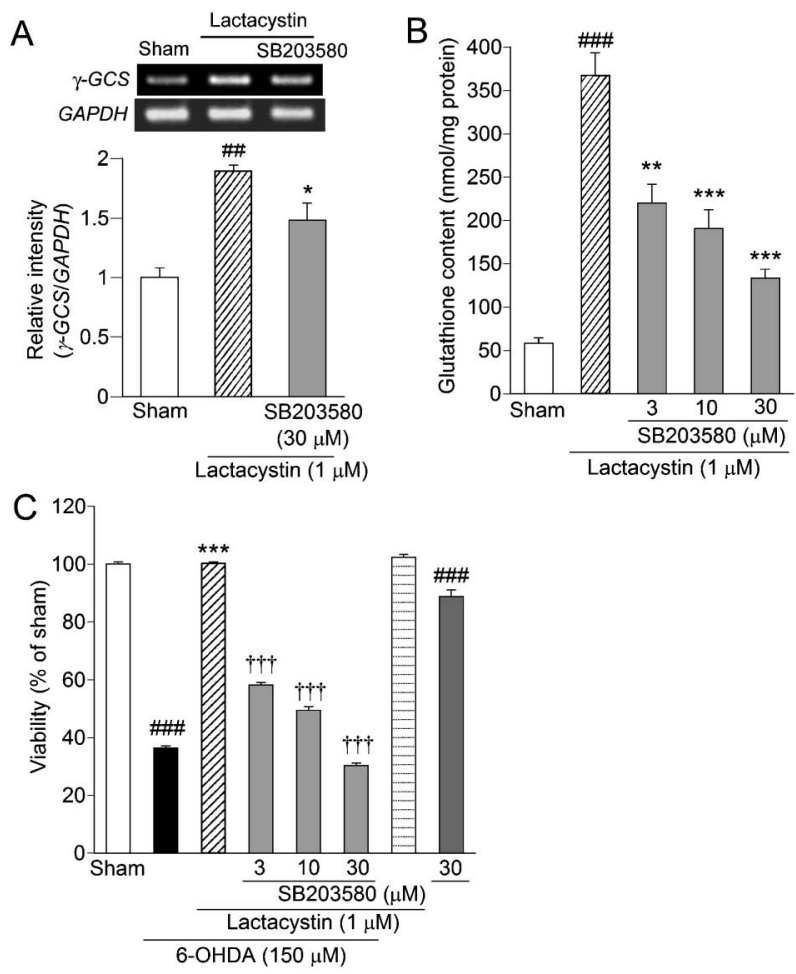

Fig. 5. Involvement of $\mathrm{p} 38$ MAPK Pathway in Cytoprotection by Proteasome Inhibition

A: Effect of SB203580 on the elevation of $\gamma$-GCS mRNA level by lactacystin. After the 12-h exposure of PC12 cells to lactacystin with or without SB203580, the expression of $\gamma$-GCS and glyceraldehyde-3-phosphate dehydrogenase (GAPDH) mRNA was analyzed by RT-PCR. B: Effect of SB203580 on the elevation of glutathione content by lactacystin. PC12 cells were treated with lactacystin for $24 \mathrm{~h}$ in the presence or absence of SB203580. C: Effect of SB203580 on cytoprotection by lactacystin. PC12 cells were pretreated with lactacystin and SB203580 for $24 \mathrm{~h}$, and exposed to 6-OHDA for $24 \mathrm{~h}$. \#\# $p<0.01$, \#\#\# $p<0.001$ vs. sham treatment. ${ }^{*} p<0.05,{ }^{* *} p<0.01$, ${ }^{* * *} p<0.001$ vs. 6-OHDA alone. ${ }^{\dagger \dagger} p<0.001$ vs. 6-OHDA + lactacystin.

ルタチオン量の上昇が惹起された。 $\gamma$-GCS 阻害薬 buthionine sulfoximine によってパラコート誘発細 胞内グルタチオン量増加を抑制すると，パラコート 毒性は増悪した。したがって，パラコート処置によ る Nrf2-ARE 経路を介した細胞内グルタチオン量 上昇は細胞保護的に働いていることが示唆された [Fig. 6]。以上の結果は，傷害を受けた細胞におい て低下したプロテアソーム活性が細胞保護的に作用 することを示唆しており，プロテアソーム活性が細 胞防御機構を調節している可能性が考えられる.

\section{4. おわりに}

本稿では，ドパミンニューロンが種々の神経毒に 対して脆弱である原因の 1 つはドパミンを含有する ことであり，プロテアソーム活性の低下は Nfr2ARE 経路を活性化し抗酸化タンパクを誘導するこ とでドパミン毒性を抑制することを紹介した。パー 


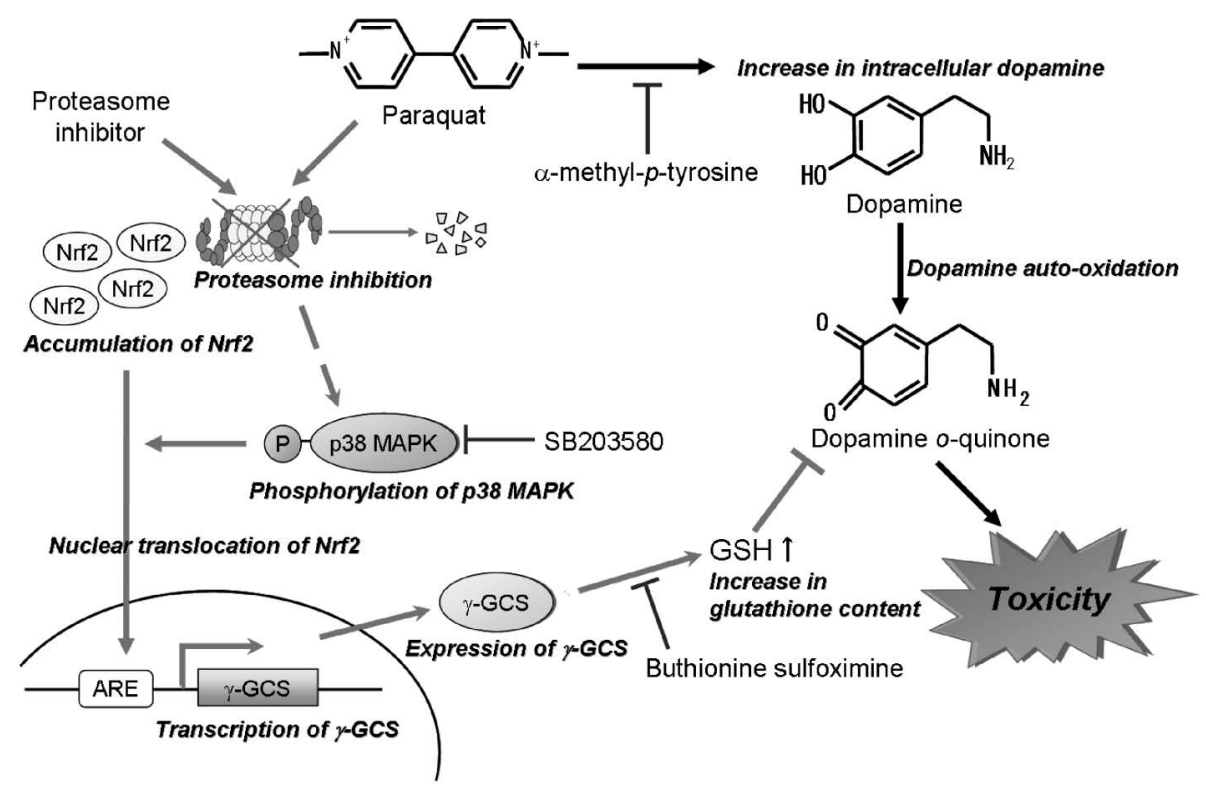

Fig. 6. A Scheme Showing the Mechanism of Paraquat-induced Dopaminergic Cytotoxicity Regulated by Endogenous Dopamine and Proteasome Activity

キンソン病患者の剖検脳におけるプロテアソーム活 性低下の意義には議論の余地はあるが，かならずし も神経変性に寄与するだけではなく, 細胞の防御機 構として機能している可能性がある。また，最近， パーキンソン病剖検脳において残存するドパミンニ ユーロンで Nrf2 の核内移行が起こっているという 興味深い報告がなされた. ${ }^{16)}$ 今後, プロテアソーム 活性とドパミンニューロン死の関係をさらに詳細に 解析することでパーキンソン病の病態解明に寄与す ると考えられる。実験的には細胞内ドパミン量を減 少させたり，プロテアソーム活性を阻害したりする ことでドパミンニューロン死を抑制することができ たが，神経伝達に必要なドパミンを枯渇させること や多様な機能に関与するプロテアソーム活性を抑制 することは臨床的には実用的ではない。しかし，そ の保護作用メカニズムを解明したところ，Nrf2ARE 経路を活性化する薬物が創薬ターゲットとし てパーキンソン病における神経保護治療に有用であ ることが見い出された。 今後，Nrf2-ARE 経路を効 率的に活性化する薬物が発見され，パーキンソン病 治療に利用されることを期待したい.

\section{REFERENCES}

1) Orimo S., Ozawa E., Nakade S., Sugimoto T., Mizusawa H., J. Neurol. Neurosurg. Psychia- try, 67, 189-194 (1999).

2) Orimo S., Uchihara T., Nakamura A., Mori F., Kakita A., Wakabayashi K., Takahashi H., Brain, 131, 642-650 (2008).

3) Sawada H., Yamakawa K., Yamakado H., Hosokawa R., Ohba M., Miyamoto K., Kawamura T., Shimohama S., JAMA, 293, 932-934 (2005).

4) Kitao Y., Imai Y., Ozawa K., Kataoka A., Ikeda T., Soda M., Nakimawa K., Kiyama H., Stern D. M., Hori O., Wakamatsu K., Ito S., Itohara S., Takahashi R., Ogawa S., Hum. Mol. Genet., 16, 50-60 (2007).

5) Xu J., Kao S. Y., Lee F. J., Song W., Jin L. W., Yankner B. A., Nat. Med., 8, 600-606 (2002).

6) Sakka N., Sawada H., Izumi Y., Kume T., Katsuki H., Kaneko S., Shimohama S., Akaike A., Neuroreport, 14, 2425-2428 (2003).

7) Izumi Y., Yamamoto N., Matsuo T., Wakita S., Takeuchi H., Kume T., Katsuki H., Sawada H., Akaike A., J. Neurochem., 110, 745755 (2009).

8) Elbaz A., Clavel J., Rathouz P. J., Moisan F., Galanaud J. P., Delemotte B., Alpérovitch A., Tzourio C., Ann. Neurol., 66, 494-504 (2009). 
9) Liou H. H., Tsai M. C., Chen C. J., Jeng J. S., Chang Y. C., Chen S. Y., Chen R. C., Neurology, 48, 1583-1588 (1997).

10) McCormack A. L., Thiruchelvam M., Manning-Bog A. B., Thiffault C., Langston J. W., Cory-Slechta D. A., Di Monte D. A., Neurobiol. Dis., 10, 119-127 (2002).

11) Izumi Y., Sawada H., Yamamoto N., Kume T., Katsuki H., Shimohama S., Akaike A., $J$. Neurosci. Res., 82, 126-137 (2005).

12) McNaught K. S., Jenner P., Neurosci. Lett., 297, 191-194 (2001).

13) Sawada H., Kohno R., Kihara T., Izumi Y., Sakka N., Ibi M., Nakanishi M., Nakamizo T., Yamakawa K., Shibasaki H., Yamamoto
N., Akaike A., Inden M., Kitamura Y., Taniguchi T., Shimohama S., J. Biol. Chem., 279, 10710-10719 (2004).

14) Nguyen T., Sherratt P. J., Huang H. C., Yang C. S., Pickett C. B., J. Biol. Chem., 278, 4536 -4541 (2003).

15) Yamamoto N., Sawada H., Izumi Y., Kume T., Katsuki H., Shimohama S., Akaike A., $J$. Biol. Chem., 282, 4364-4372 (2007).

16) Ramsey C. P., Glass C. A., Montgomery M. B., Lindl K. A., Ritson G. P., Chia L. A., Hamilton R. L., Chu C. T., Jordan-Sciutto K. L., J. Neuropathol. Exp. Neurol., 66, 75-85 (2007) 